\title{
HPV: Obvious but Not Necessary Cause of Cervical Cancer
}

\author{
Gamze Mocan ${ }^{1,2}$ (D), Pınar Tulay ${ }^{3,4}$ (D), Hanife Özkayalar' (D), Nedime Serakıncı ${ }^{3}$ (D) \\ 'Department of Medical Pathology, Near East University School of Medicine, Nicosia, Cyprus \\ 2Department of Medical Biology, Near East University School of Medicine, Nicosia, Cyprus \\ ${ }^{3}$ Department of Medical Genetics, Near East University School of Medicine, Nicosia, Cyprus \\ ${ }^{4}$ Near East University, DESAM Institute, Nicosia, Cyprus
}

ORCID iDs of the authors: H. Ö. 0000-0002-II05-4085; P. T. 0000-0002-6793-7805; G. M. 0000-0002-7625-4934; N. S. 0000-0002-I8840839.

Cite this article as: Mocan G, Tulay P, Özkayalar H, Serakıncı N. HPV: Obvious but Not Necessary Cause of Cervical Cancer. Cyprus J Med Sci 2020; 5(2): 107-12.

\section{BACKGROUND/AIMS}

Cervical cancer is one of the most common cancers worldwide. Human papilomavirus (HPV) has been proposed to be one of the main players in the development of cervical cancer. The aim of this study was to investigate the association of HPV DNA and cervical cytology.

\section{MATERIAL and METHODS}

A total of 201 women undergoing routine gynaecological check up in Hospital were recruited. HPV genotyping and cervical Pap test were analysed.

\section{RESULTS}

Overall, $42 \%$ ( $85 / 20 \mathrm{I}$ ) of women analysed were tested positive for at least one of the HPV types tested. HPV DNA prevalence was the highest in women younger than 30 years old $(59 \%, 50 / 85)$. Eighty four percent (7I/85) of the HPV positive women had low to high grade cytological anomalies.

\section{CONCLUSION}

The presence of HPV DNA was strongly associated with the cytological anomalies, especially with specific HPV types. This study showed that detection of multiple HPV types is rather important in understanding the possible crosstalk among HPVs during the initiation and progression of cervical lesions. In conclusion, HPV still remains to be the most prevalent marker for cervical cancer and thus regular check up should be evaluated as a preventative policy for cervical cancer.

Keywords: Cervical cancer, cytological pathology, HPV

\section{INTRODUCTION}

Cervical cancer is the third most common cancer affecting almost half a million women worldwide. Human papilomavirus (HPV) poses a substantial risk for the development of cervical cancer and genital HPV infections are associated with more than $99 \%$ of all cervical cancers $(I, 2)$. HPVs are small, non-enveloped viruses with double stranded circular DNA compromising almost 8000 nucleotide base pairs $(3,4)$. Up to date, over 180 different types of HPVs have been completely sequenced $(5,6)$ and all these HPVs are shown to infect the epithelial cells usually either the cutaneous or the mucosal surfaces. Neoplastic changes are mainly caused by HPVs with high oncogenic potential (high risk, HR-HPV) (7). Women with HPVI6 (61\%) and HPVI8 (I0\%) were shown to have 200-fold higher risks for cervical cancer $(3,8)$. The prevalence of other HPV types are less observed in cervical cancer cases, in such HPV45 was observed in 6\%, HPV3I in 4\%, HPV52 in $3 \%, H P V 35$ in $2 \%$ and HPV58 in $2 \%$ of cervical cancer cases (9). HPVs, mainly HR-HPVs, have also been observed in women with intermediate grade cervical cytological abnormalities that may progress to cervical cancer, such as atypical squamous cells of undetermined significance (ASCUS) and low-grade squamous epithelial lesions (LSIL) (2, I0, II).

The association between the oncogenic HPV types and the subsequent development of cervical cancer has introduced the detection of HPV DNA as an alternative or supplementary screening and early detection strategy (I2). Therefore, with a well-designed screening programme involving HPV genotyping and cytological analysis, unnecessary operations, such 
as colposcopies, can be prevented. Moreover, with an established policy, early detection of cervical cancer will improve the mortality and morbidity. Hence, in this study we aimed to assess the prevalence of HPV infection in relation to cytological diagnosis in women undergoing routine gynaecological check up. In this way, the association between the presence of HPV DNA and development of cervical abnormalities can be predicted and appropriate treatment can be applied in advance.

\section{MATERIAL and METHODS}

Study Population: Physical Examination and Specimen Collection Ethical approval conforming to the provisions of the Declaration of Helsinki was granted and written consensus was obtained from each patient. Women between the ages of 19-57 years old undergoing routine gynaecological check-up in Hospital were recruited into this prospective study investigating the correlation between the prevalence of HPV DNA and the cytological findings. Each participant had a pelvic examination at enrolment and exfoliated cervical cells were obtained for cytological analysis and for HPV DNA testing. Informed consent was received from each patient.

\section{Cytological Assessment}

The cervical cells were spread on microscope slide and fixed for the cytological assessment. The samples were stained with $\mathrm{Pa}-$ panicolaou (Pap) stain (BD Sure Path liquid based Pap Test; Papnicolou's solution, Merck) within the Laboratory of Pathology, Hospital. Pap smear samples were analysed by trained cytopathologists and the cytological smears were classified following 2014 Bethesda system $(13,14)$. In brief, the samples were classified as; no epithelial cell anomaly, atypical squamous cell of undetermined significance (ASC-US), atypical squamous cells with high grade squamous intraepithelial lesion (ASC-H), low grade squamous intraepithelial lesion (LSIL) and high grade squamous intraepithelial lesion (HSIL). The presence of fungal or bacterial infection as well as inflammation was also reported.

\section{HPV DNA Testing}

HPV DNA testing of all the participants was performed on cervical cell samples at the Medical Genetics and Cancer Diagnosis-Research Centre, Hospital. DNA was extracted using GeneAll ${ }^{\circledR}$ Ribo_spin vRD ${ }^{T M}$ kit (Gene All, Gambio) and DNA was tested using Seeplex ${ }^{\circledR}$ HPV4A ACE Screening kit (Seeplex, Seegene) following manufacturer's instructions. This kit uses the principle of "Dual Priming Oligonucleotide (DPO) technology" maximising PCR specificity and sensitivity by fundamentally blocking non-specific priming. Internal control and positive control provided within the Seeplex ${ }^{\circledR}$ HPV4A ACE Screening kit were included for each reaction. DNA was tested for the simultaneous genotyping of the high-risk HPV types, HPVI6 and HPVI8, and screening of 16 additional high-risk HPV types (HRC) including

\section{Main Points:}

- Detection of multiple HPV types is rather important.

- There is a possible crosstalk among HPVs during the initiation and progression of cervical lesions.

- HPV still remains to be the most prevalent marker for cervical cancer.
HPV26, 31, 33, 35, 39, 45, 51, 52, 53, 56, 58, 59, 66, 68, 73 and 82 and low risk HPV types, HPV6/II. The presence of HPV DNA was assessed by observing the band with appropriate product size on etihidium bromide stained ( $2 \% /$ Ixtris borate EDTA) agarose gel electrophoresis. The presence of HPVI6 was detected with a band at 588bp, HPVI8 at 230bp, HRC at 465bp, and HPV6/II at $302 \mathrm{bp}$ with an internal control at l000bp.

\section{Statistical Analysis}

The prevalence of HPV DNA was correlated according to the women's age. Two-tailed student's t-test was used for the analysis of distribution of high-grade cytological findings among HPV positive and negative women. A $p<0.05$ was considered statistically significant. All statistical analysis was conducted using GrapPad prims v6 (California, USA.)

\section{RESULTS}

\section{HPV DNA Detection}

The study population was composed of 201 women aged between 19 and 57 years old with the median age of 30 . Of these women, $45 \%(85 / 201)$ were tested positive for at least one of the HPV types tested. HPV DNA prevalence was the highest in women younger than 30 years old $(59 \%, 50 / 85)$ though these values were not statistically significant compared to women older than the age of 30 years old ( $p>0.05$, Table I). Only six women had two sexual partners and two of these women were tested positive for HPV.

Overall, the presence of HPVI6 was detected in $10.9 \%(22 / 201)$ of the women tested, HPVI8 in $2.9 \%$ (6/20I), HPV6/II in 10.9\% $(22 / 20 \mathrm{I})$ and at least one of the HRC group of HPVs in $28.9 \%$ (58/20l; Table 2).

Among HPV positive women 92\% (I85/20I) were tested positive for one HPV type (excluding the analysis of HRC) whereas the rest of the women had multiple HPV types detected. All of these women were positive for at least one type of high-risk HPV and 65\% (II/I7) have multiple high-risk HPVs detected. Thirty six percent (8/22) of HPVI6 positive women were also screened positive for HRC and $18 \%$ (4/22) for HPV6/II.

\section{Cytological Diagnosis}

Cytological assessments of cervical cells revealed that $14 \%$ $(12 / 85)$ of the HPV positive women did not have any cytological abnormalities (Table 3 ). The rest of the women have at least one kind of abnormal cervical cytology ranging from epithelial cell

\begin{tabular}{|c|c|c|c|c|}
\hline \multirow[b]{2}{*}{$\begin{array}{l}\text { Age } \\
\text { groups }\end{array}$} & \multicolumn{2}{|c|}{ HPV DNA positive } & \multicolumn{2}{|c|}{ HPV DNA negative } \\
\hline & $\begin{array}{l}\text { Number of } \\
\text { women }\end{array}$ & $\begin{array}{c}\% \\
\text { (Percentage) }\end{array}$ & $\begin{array}{l}\text { Number of } \\
\text { women }\end{array}$ & $\begin{array}{c}\% \\
\text { (Percentage) }\end{array}$ \\
\hline$<30$ & 50 & 59 & 41 & 35 \\
\hline $30-40$ & 22 & 26 & 41 & 35 \\
\hline $4 \mid-55$ & 12 & 14 & 31 & 26 \\
\hline$>55$ & । & । & 3 & 3 \\
\hline Total & 85 & & 116 & \\
\hline
\end{tabular}


anomalies to LSIL and HSIL. Overall, abnormal cytological outcome was observed to be more common in HPV positive women $(90 \%, 76 / 85$, of women) compared to HPV negative women (76\%, 89/116, Table 3). In HPV positive women low grade cervical abnormalities, such as LSIL (22\%) were detected. Additionally, bacterial vajinozis within the vaginal flora $(3 \%, 5 / 85)$, fungal infection morphologically similar to candida $(6 \%, 5 / 85)$ and inflammation (23\%, 20/85), were also detected in HPV positive women. Thirty six percent $(32 / 85)$ of HPV positive women were diagnosed to have epithelial cell anomalies, 17\% (15/85) with ASCUS, I\% (I/85) with ASC-H, 22\% (I/85) with LSIL, 8\% (6/85) with HSIL (Table 3).

\section{TABLE 2. Distribution of HPV types}

\begin{tabular}{|lccc|}
$\begin{array}{l}\text { HPV } \\
\text { type }\end{array}$ & $\begin{array}{c}\text { Number of } \\
\text { women }\end{array}$ & $\begin{array}{c}\text { Overall } \\
\text { percentage }(\%)\end{array}$ & $\begin{array}{c}\text { Percentage among HPV } \\
\text { positive women (\%) }\end{array}$ \\
\hline HPVI6 & 22 & 10.9 & 29 \\
HPVI8 & 6 & 2.9 & 7 \\
HPV6/II & 19 & 10.9 & 22 \\
HRC & 58 & 28.9 & 68 \\
\hline HPV: human papillomavirus; HRC: high-risk HPV types & \\
\hline
\end{tabular}

\section{Association of HPV Types with Cytological Diagnosis}

Overall, 23\% (5/22) of the HPVI6 positive women did not present any cytological anomalies and the rest had at least one aberrant cytological diagnosis ranging from low, intermediate and highgrade cervical anomalies. The findings of cytological diagnoses are summarised in table 4 . The low-grade cervical anomalies of HPVI6 positive women included bacterial vajinozis, fungal infection, warts, inflammation as well as epithelial cell abnormalities. Intermediate and high-grade cervical lesions for HPVI6 positive women included ASCUS (18\%, 4/22), LSIL (18\%, 4/22) and HSIL $(9 \%, 2 / 22)$ (Figure I). The number of women tested positive for HPVI8 is low; however, half these women were diagnosed for ASCUS, 33\% (2/6) for LSIL and 17\% (I/6) for HSIL. The highest detection of HSIL $(26 \%, 5 / 19)$ was reported in HPV6/II positive women. Presence of warts and ASCUS were detected in $26 \%(5 / 19)$ of the HPV6/II positive women (Table 4, Figure I). For the HRC positive women, epithelial cell abnormalities were detected in 38\% (22/58) followed by $24 \%$ (14/58) LSIL and 21\% (12/58) ASCUS.

The risk of having LSIL was considerably increased $(p<0.05)$ when the women were HPVI6 positive as well as HRC positive, in such cytological diagnosis for half of the HPVI6 and HRC positive women revealed that they have LSIL. Although the rate of

\section{TABLE 3. Association of HPV with cytological diagnosis}

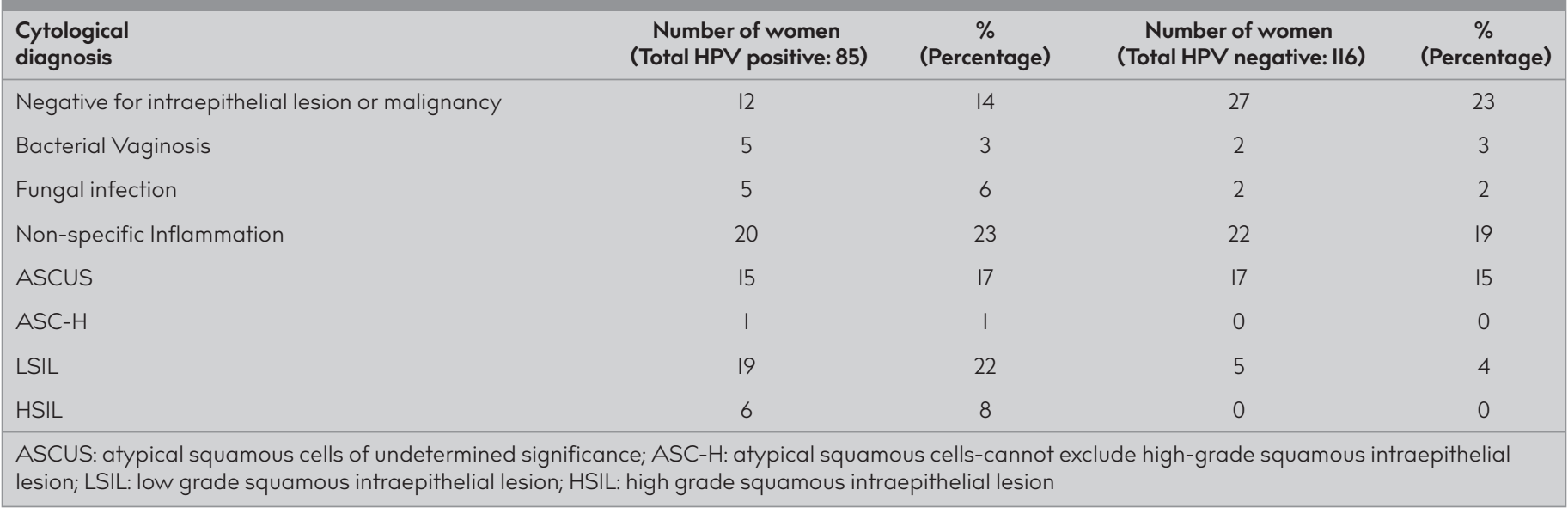

TABLE 4. Association of HPV prevalence with cytological outcome

\begin{tabular}{|c|c|c|c|c|}
\hline $\begin{array}{l}\text { Cytological } \\
\text { diagnosis }\end{array}$ & $\begin{array}{c}\text { Percentage of women } \\
\text { with HPVI6 }\end{array}$ & $\begin{array}{c}\text { Percentage of women } \\
\text { with HPVI8 }\end{array}$ & $\begin{array}{c}\text { Percentage of women } \\
\text { with HPV6/II }\end{array}$ & $\begin{array}{c}\text { Percentage of women } \\
\text { with HRC }\end{array}$ \\
\hline No abnormalities & 23 & 0 & 16 & 14 \\
\hline Epithelial cell abnormalities & 27 & 2 & 21 & 38 \\
\hline Bacterial vajinozis & 5 & 0 & 5 & 3 \\
\hline Fungal infection & 5 & 0 & 5 & 2 \\
\hline ASCUS & 18 & 50 & 26 & 21 \\
\hline ASC-H & 0 & 0 & 0 & 2 \\
\hline LSIL & 18 & 33 & 21 & 24 \\
\hline HSIL & 9 & 17 & 26 & 2 \\
\hline
\end{tabular}

HPV: human papillomavirus; HRC: high-risk HPV types; ASCUS: atypical squamous cells of undetermined significance; ASC-H: atypical squamous cells-cannot exclude high-grade squamous intraepithelial lesion; LSIL: low grade squamous intraepithelial lesion; HSIL: high grade squamous intraepithelial lesion 

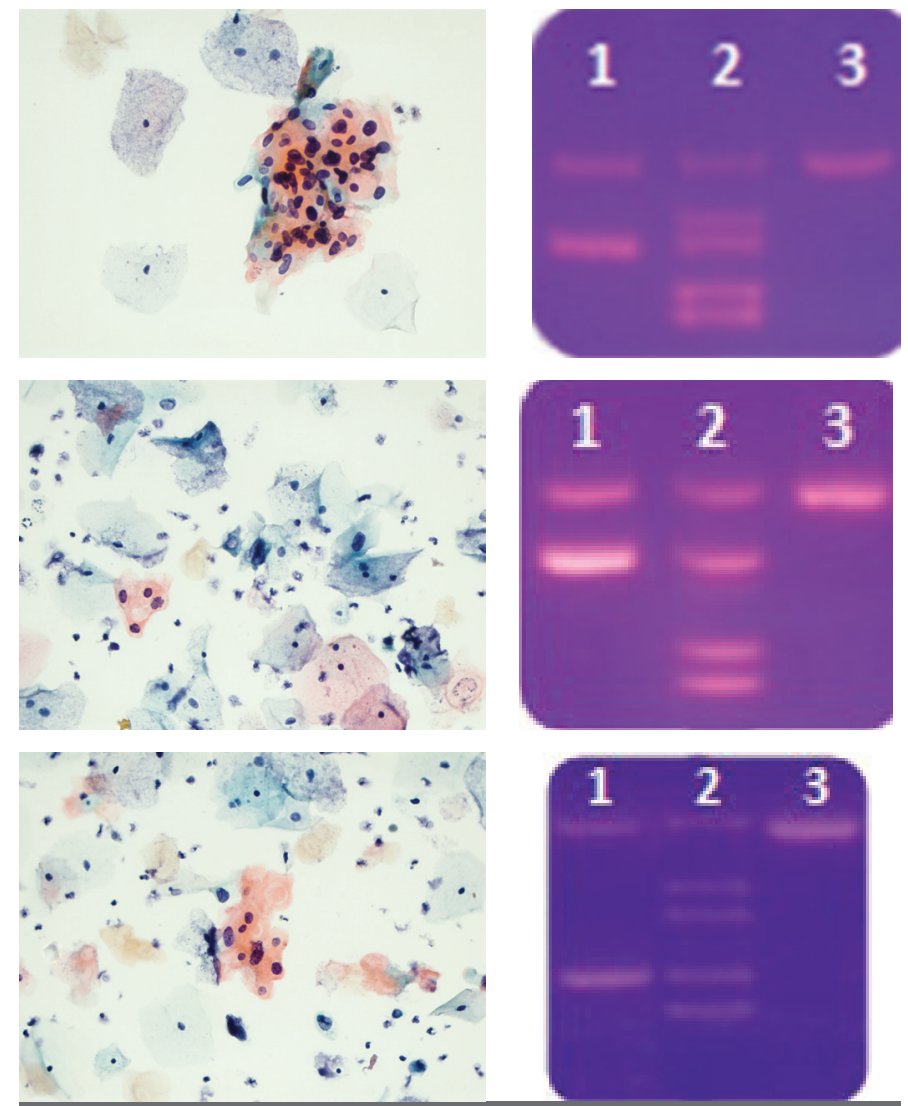

FIGURE I. Diagram showing the pathology and HPV genotyping results

Results of pathological analysis are shown in (a) and the HPV DNA genotyping is shown in (b). Lane I represents the patient's DNA, lane 2 represents the marker with a band at $1000 \mathrm{bp}$ for internal control, 588bp for HPVI6, 302bp for HPV6/II and 230bp for HPVI8. Lane 3 represents the negative control with only a band at $1000 \mathrm{bp}$ for the internal control. a) Results of a patient diagnosed for $i$. ASCUS following pathological analysis and ii. HPV6/Il following HPV DNA genotyping at lane I. b) Results of a patient diagnosed for i. LSIL following pathological analysis and ii. HPVI6 following HPV DNA genotyping at lane I. c) Results of a patient diagnosed for i. HSIL following pathological analysis and ii. HRC following HPV DNA genotyping at lane I. Abbreviations: Aypical squamous cells of undetermined significance (ASCUS), low grade squamous intraepithelial lesion (LSIL) and high grade squamous intraepithelial lesion (HSIL).

having HSIL is supposed to be higher when women are positive for more than one HR-HPVs, this study showed that the rates were almost similar in developing HSIL for woman tested HPVI6 and HRC positive.

\section{DISCUSSION}

High risk HPV types are well known to cause cervical cancer and HPV DNA is detected in approximately $99.7 \%$ of cervical cancer tissue specimens (I). Therefore, HPV genotyping is important to investigate the natural history of the infections and whether the infection of HPV is involved in the initiation and progression of cervical cancer lesions $(15,16)$. With the use of HPV DNA detection strategies, early detection and screening provided tremendous improvement for cervical cancer diagnosis (17). In this study, we present the type specific prevalence of HPVs providing a picture of the frequency of genital infections caused by these mucosal HPVs and estimating the risk of cervical cancer development.
HPV DNA was detected in $42 \%$ of 20 I women. Worldwide, the prevalence of HPV infection among women was estimated to range between $2 \%$ and $44 \%$ (18). In general, high risk HPV types are observed at a higher rate in women younger than 30 years $(19,20)$ which is in agreement with this study, though there are some controversies showing increased prevalence of HPV in the older age group (2I), in such high risk HPVs (HPVI8 and HPV5I) were associated with HSIL (22). All these variabilities among different outcomes including the present study could be due to different techniques used or population differences such as analysis of both normal and abnormal cytologies that may lower the rates of HPV prevalence.

Twelve percent (14/85) of the HPV positive women had normal cytology which is in accordance with the current literature. In confirmation for the carcinogenic role of the high-risk HPV types, cytological diagnosis of the women including low, intermediate and high-grade cervical anomalies were compared to women with normal cytology. The prevalence of epithelial cell anomalies, LSIL and HSIL were shown to be statistically significant in HR-HPV positive women compared to HPV negative women $(p<0.05)$. The prevalence of the HRC types followed by HPVI6 was higher in women with epithelial cell anomalies. The prevalence of HPVI6 and HPVI8 was also relatively high in women diagnosed for LSIL and ASCUS as also reported previously (23). The prevalence of different HPV type differs depending on the ethnic group, such as in Botswana women HPV was associated most with HSIL (24). Similar to our findings, HPV positive women were shown to have increased cytological anomalies of LSIL (50\%), HSIL (I00\%) and invasive cervical cancer (II, 19). In this study, HSIL in addition to genital warts and inflammation were mostly detected in HPV6/II positive women. HPV6 and HPVII have been mostly associated with genital warts and condyloma acuminatum, whereas HPVI6 and HPVI8 to be the main cause of cervical cancer development (25-27).

Among HPV positive women, $20 \%$ to $40 \%$ have been reported to harbor at least two HPV types $(8,12,28-30)$. The idea of the presence of one HPV type increasing the likelihood of attaining another HPV type is still controversial. Although it is suspected that presence of multiple HPV types increases the risk of the persistency of HPV and cervical lesions, it remains to be one of the debates due to the unknown biological activity of these HPVs and the viral load (3I, 32). In this study, $8 \%(17 / 201)$ of the women were infected with multiple HPV types and in this study, women tested positive for more than one HPV type did not have an increased rate of having cytological anomalies. Since coinfections are shown to be more frequent among women with cytological abnormalities or impaired immune response (33-35), development of cytological anomalies could be due to the patient history profile as well.

One of the other factors affecting the prevalence of genital HPV infection is the number of sexual partners. In this study only 2 of 6 women with two sexual partners were tested positive for $H P V ;$ hence having more than one partner did not seem to have the main reason of HPV infection. Although the main factors increasing the HPV infections accounts for multiple sexual partners, other factors increases the rate of HPV infection including the presence of other sexually transmitted infections, smoking, immunosupression, use of oral contraceptives, hormonal thera- 
py, age of the first sexual intercourse and sexual behaviours of the male partner (36-42).

One of the main limitations of this study involves the cross-sectional design and the lack of analysis of temporal relationship between the HPV detection and the cytological outcome that may have developed at a later stage. Therefore, prospective studies play a crucial role in understanding the association of the presence of HPV DNA, the persistency of the infection and the risk of cervical lesion formation. The types of HPVs analysed in this study is also limited since genotyping is performed for the high-risk HPV types HPVI6 and HPVI8 and screening is performed for the other high risk HPV types including HPV26, 31, 33, $35,39,45,51,52,53,56,58,59,66,68,73$ and 82 and low risk HPV types HPV6 and HPVII.

In conclusion, detection of multiple HPV types is rather important in understanding the possible crosstalk among HPVs during the initiation and progression of cervical lesions. Our study provides information on the association and distribution of different HPV types with cytological assessment enabling better outcome measures and early detection and screening for cervical cancer. Overall, this study highlights the importance of identifying the prevalence of HPV types that may define the causality of individual HPV types with cervical cancer and form the basis for secondary prevention measures for cervical cancer and the need of longitudinal studies on the natural history of HPV. In the light of the literature and as it is seen with our results, HPV still remains to be the most prevalent marker for cervical cancer and thus regular check up should be evaluated as a preventative policy for cervical cancer.

Ethics Committee Approval: Ethics committee approval was received for this study from the ethics committee of Near East University (YDU/2020/77=1021).

Informed Consent: Written informed consent was obtained from patients who participated in this study.

Peer-review: Externally peer-reviewed.

Author Contributions: Concept - G.M., N.S.; Design - G.M., N.S., P.T., H.O.; Supervision - G.M., N.S., P.T., H.O.; Resources - G.M., N.S.; Materials - G.M., N.S.; Data Collection and/or Processing - G.M., N.S., H.O.; Analysis and/ or Interpretation - G.M., N.S., P.T., H.O.; Literature Search - P.T., H.O., Writing Manuscript - P.T., H.O.; Critical Review - G.M., N.S., P.T., H.O.

Acknowledgements: We would like to thank all the hospital employee and the patients who consented for this research.

Conflict of Interest: Authors have no conflicts of interest to declare.

Financial Disclosure: The authors declared that this study has received no financial support.

\section{REFERENCES}

I. Walboomers JM, Jacobs MV, Manos MM, Bosch FX, Kummer JA, Shah KV, et al. Human papillomavirus is a necessary cause of invasive cervical cancer worldwide. J Pathol 1999; 189(I): 12-9. [Crossref]

2. Forman D, de Martel C, Lacey CJ, Soerjomataram I, Lortet-Tieulent J, Bruni L, et al. Global burden of human papillomavirus and related diseases. Vaccine 2012; 30(Suppl 5): Fl2-23. [Crossref]
3. Muñoz N, Bosch FX, de Sanjosé S, Herrero R, Castellsagué $X$, Shah $\mathrm{KV}$, et al. Epidemiologic classification of human papillomavirus types associated with cervical cancer. N Engl J Med 2003; 348(6): 5I8-27. [Crossref]

4. Schiffman M, Clifford G, Buonaguro FM. Classification of weakly carcinogenic human papillomavirus types: addressing the limits of epidemiology at the borderline. Infect Agent Cancer 2009; 4: 8. [Crossref]

5. de Villiers EM, Fauquet $\mathrm{C}$, Broker TR, Bernard HU, zur Hausen $\mathrm{H}$. Classification of papillomaviruses. Virology 2004; 324(I): 17-27. [Crossref]

6. Bernard HU, Burk RD, Chen Z, van Doorslaer K, zur Hausen H, de Villiers EM. Classification of papillomaviruses (PVs) based on 189 PV types and proposal of taxonomic amendments. Virology 2010; 40I(I): 70-9. [Crossref]

7. Rodríguez AC, Schiffman M, Herrero R, Hildesheim A, Bratti C, Sherman ME. Longitudinal study of human papillomavirus persistence and cervical intraepithelial neoplasia grade 2/3: critical role of duration of infection. J Natl Cancer Inst 2010; 102(5): 315-24. [Crossref]

8. Bosch FX, Lorincz A, Muñoz N, Meijer CJLM, Shah KV. The causal relation between human papillomavirus and cervical cancer. J Clin Pathol 2002; 55(4): 244-65. [Crossref]

9. Schiffman M, Kjaer SK. Chapter 2: Natural history of anogenital human papillomavirus infection and neoplasia. J Natl Cancer Inst Monogr 2003; (31): 14-9. [Crossref]

10. de Sanjosé S, Diaz M, Castellsagué X, Clifford G, Bruni L, Muñoz N, et al. Worldwide prevalence and genotype distribution of cervical human papillomavirus DNA in women with normal cytology: a meta-analysis. Lancet Infect Dis 2007; 7(7): 453-9. [Crossref]

II. Bzhalava D, Guan P, Franceschi S, Dillner J, Clifford G. A systematic review of the prevalence of mucosal and cutaneous human papillomavirus types. Virology 2013; 445(I-2): 224-31. [Crossref]

12. Zhang $L, B i Q$, Deng $H, X \cup J$, Chen J, Zhang $M$, et al. Human papillomavirus infections among women with cervical lesions and cervical cancer in Eastern China: genotype-specific prevalence and attribution. BMC Infect Dis 2017; 17(I): 107. [Crossref]

13. Solomon D, Davey D, Kurman R, Moriarty A, O'Connor, Prey M, et al. The 200l Bethesda System: terminology for reporting results of cervical cytology. JAMA 2002; 287(I6): 2114-9. [Crossref]

14. Nayar R, Wilbur DC. The Pap test and Bethesda 2014. Cancer Cytopathol 20I5; 123(5): 27I-8I. [Crossref]

15. Kyrgiou M, Kalliala IEJ, Mitra A, Fotopoulou C, Ghaem-Maghami S, Martin-Hirsch PPL et al. Immediate referral to colposcopy versus cytological surveillance for minor cervical cytological abnormalities in the absence of HPV test. Cochrane Database Syst Rev 2017; 26(I). [Crossref]

16. Tota JE, Bentley J, Blake J, Coutlée F, Duggan MA, Ferenczy A, et al. Introduction of molecular HPV testing as the primary technology in cervical cancer screening: Acting on evidence to change the current paradigm. Prev Med 2017; 98: 5-14. [Crossref]

17. Cuzick J, Arbyn M, Sankaranarayanan R, Tsu V, Ronco G, Mayrand $\mathrm{MH}$, et al. Overview of human papillomavirus-based and other novel options for cervical cancer screening in developed and developing countries. Vaccine 2008; 26(Suppl I0): K29-4l. [Crossref]

18. Stanley M. Pathology and epidemiology of HPV infection in females. Gynecol Oncol 2010; II7(2 Suppl): S5-10. [Crossref]

19. Sahiner F, Gümral R, Sener K, Yiğit N, Dede M, Yapar M, et al. Investigation of HPV-DNA in cervical smear samples by PCR methods. IJAPBC 2014; 3(4): 1064-73.

20. Baseman JG, Koutsky LA. The epidemiology of human papillomavirus infections. J Clin Virol 2005; 32(Suppl I): SI6-24. [Crossref]

21. Woodman CB, Collins SI, Young LS. The natural history of cervical HPV infection: unresolved issues. Nat Rev Cancer 2007; 7(I): II-22. [Crossref]

22. Gutiérrez MRM, Cuns CA, Gómez Dorronsoro ML, Paniello Alastruey I, Mallor Giménez F, Lozano Escario MD, et al. Influence of Age 
in the Prevalence of High-Risk Human Papiloma Virus in Women with Pre-Neoplasic Cervical Lesions in Navarra, Spain. Rev Esp SaIud Publica 2017; 91: e201702018.

23. Kemunto Ogembo r, Nyakauru Gona P, Seymour AJ, Soo-Min Park $H$, Bain PA, Maranda L, et al. Prevalence of Human Papillomavirus Genotypes among African Women with Normal Cervical Cytology and Neoplasia: A Systematic Review and Meta-Analysis. PLoS One 2015; I0(4): e0I22488. [Crossref]

24. Ranthshabeng P, Kasvosve I, Ndlovu A, Gaseitsiwe S, Moyo S. Prevalence of high-risk human papilloma virus in women with high-grade squamous cell intraepithelial lesions in Botswana using Abbott RealTime HPV assay. PLoS One 2019; I4(I): e0211260. [Crossref]

25. Kantathavorn N, Mahidol C, Sritana N, Sricharunrat T, Phoolcharoen N, Auewarakul C, et al. Genotypic distribution of human papillomavirus (HPV) and cervical cytology findings in 5906 Thai women undergoing cervical cancer screening programs. Infect Agent Cancer 2012. 10: p. 7. [Crossref]

26. Li AX, Yin r, Zhong B, Haoet F. (Clinical analysis of the infection with human papillomavirus in women). Zhonghua Shi Yan He Lin Chvang Bing Du Xue Za Zhi 2006; 20(2): 49-52.

27. Petry KU, Petry KU, Luyten A, Justus A, Iftner A, Strehlke S, Schulze-Rath R et al. Prevalence of low-risk HPV types and genital warts in women born 1988/89 or 1983/84 -results of WOLVES, a population-based epidemiological study in Wolfsburg, Germany. BMC Infect Dis 2015; 12: 367. [Crossref]

28. Han J, Swan DC, Smith SC, Lum SH, Sefers SE, Unger ER, et al. Simultaneous amplification and identification of 25 human papillomavirus types with Templex technology. J Clin Microbiol 2006; 44(II): 4157-62. [Crossref]

29. Mendez F, Munoz N, Posso H, Molano M, Moreno V, van den Brule AJC, et al. Cervical coinfection with human papillomavirus (HPV) types and possible implications for the prevention of cervical cancer by HPV vaccines. J Infect Dis 2005; 192(7): II58-65. [Crossref]

30. Schmitt M, Dondog B, Waterboer T, Pawlita M. Homogeneous amplification of genital human alpha papillomaviruses by PCR using novel broad-spectrum GP5+ and GP6+ primers. J Clin Microbiol 2008; 46(3): 1050-9. [Crossref]

31. Rousseau MC, Pereira JS, Mann Prado JC, Villa LL. Cervical coinfection with human papillomavirus (HPV) types as a predictor of acquisition and persistence of HPV infection. J Infect Dis 200l; 184(12): 1508-17. [Crossref]
32. Schiffman MH, Bauer HM, Hoover RN, Glass AG, Cadell DM, Rush $\mathrm{BB}$, et al. Epidemiologic evidence showing that human papillomavirus infection causes most cervical intraepithelial neoplasia. J Natl Cancer Inst 1993; 85(12): 958-64. [Crossref]

33. Levi JE, Kleter B, Quint WGV, Fink MCS, Canto CLM, Matsubara R, et al. High prevalence of human papillomavirus (HPV) infections and high frequency of multiple HPV genotypes in human immunodeficiency virus-infected women in Brazil. J Clin Microbiol 2002; 40(9): 334I-5. [Crossref]

34. Herrero R, Hildesheim A, Bratti C, Sherman ME, Hutchinson M, Morales $J$, et al. Population-based study of human papillomavirus infection and cervical neoplasia in rural Costa Rica. J Natl Cancer Inst 2000; 92(6): 464-74. [Crossref]

35. Cuschieri KS, Cubie HA, Whitley MW, Seagar AL, Arends MJ, Moore $C$, et al. Multiple high risk HPV infections are common in cervical neoplasia and young women in a cervical screening population. $J$ Clin Pathol 2004; 57(I): 68-72. [Crossref]

36. Wang KL. Human papillomavirus and vaccination in cervical cancer. Taiwan J Obstet Gynecol 2007; 46(4): 352-62. [Crossref]

37. Franco EL, E Duarte-Franco, Ferenczy A. Cervical cancer: epidemiology, prevention and the role of human papillomavirus infection. CMAJ 2001; 164(7): 1017-25.

38. Dunne EF, Unger ER, Sternberg M, McQuillan G, Swan DC, Patel SS, et al. Prevalence of HPV infection among females in the United States. JAMA 2007; 297(8): 813-9. [Crossref]

39. Frega A, Frega A, Scardamaglia P, Piazze J, Cerekja A, Pacchiarotti $A$, Verrico $M$, et al. Oral contraceptives and clinical recurrence of human papillomavirus lesions and cervical intraepithelial neoplasia following treatment. Int J Gynaecol Obstet 2008; 100(2): 175-8. [Crossref]

40. Mohllajee AP, Mohllajee AP, Curtis KM, Martins SL, Peterson HB. Hormonal contraceptive use and risk of sexually transmitted infections: a systematic review. Contraception 2006; 73(2): 154-65. [Crossref]

4l. Moreno V, Bosch FX, Muñoz N, Meijer CJLM, Shah KV, Walboomers $J M M$, et al. Effect of oral contraceptives on risk of cervical cancer in women with human papillomavirus infection: the IARC multicentric case-control study. Lancet 2002; 359(9312): 1085-92. [Crossref]

42. Castellsague X, Munoz N. Chapter 3: Cofactors in human papillomavirus carcinogenesis--role of parity, oral contraceptives, and tobacco smoking. J Natl Cancer Inst Monogr 2003(31): 20-8. [Crossref] 